\title{
Pengenalan Makna dan Simbol Perangkat Tanaman Adat dalam Ritual Modutu Antaran Gorontalo
}

\author{
Ellyana Hinta ${ }^{1 凶}$, Sitti Rachmi Masie ${ }^{2}$, Asna Ntelu ${ }^{3}$, Harto S. Malik ${ }^{4}$ \\ Fakultas Sastra dan Budaya, Universitas Negeri Gorontalo \\ DOI: $10.31004 /$ obsesi.v5i2.835
}

\begin{abstract}
Abstrak
Tujuan penelitian dari artikel ini adalah untuk mendeskripsikan pengenalan makna dan simbol perangkat tanaman adat dalam ritual modutu antaran bagi anak usia dini di Gorontalo. Metode penelitian yang digunakan adalah metode penelitian deskriptif kualitatif. Peneliti melakukan tahapan implementasi pengenalan makna dan simbol perangkat tanaman adat dalam ritual modutu antaran bagi anak usia dini. Analisis data yang digunakan adalah analisis data menggunakan persentase dan kriteria. Hasil penelitian menunjukkan bahwa implementasi pengenalan makna dan simbol tersebut tidak menemui kendala yang berarti, respon orang tua dan anak-anak usia dini sangat antusias meskipun beberapa anak tampak kebingunan terhadap makna dan simbol yang diberikan. Kebaruan penelitian didapatkan bahwa orang tua saat ini tidak terlalu paham dan dapat mempertahankan ritual tersebut secara utuh. Dampak dan impak dari hasil penelitian ini adalah perlunya dilestarikan kembali ritual Modutu agar anak-anak sebagai penerus tidak punah digilas zaman.
\end{abstract}

Kata Kunci: pengenalan; makna; simbol; tanaman adat; modutu; Gorontalo; anak usia dini.

\begin{abstract}
The research objective of this article is to describe the introduction of the meaning and symbols of traditional plant tools in the modutu antaran ritual for early childhood in Gorontalo. The research method used is descriptive qualitative research methods. The researcher carried out the stages of implementing the recognition of the meaning and symbols of traditional plant tools in the ritual of introducing the meanings and symbols for early childhood. The data analysis used was data analysis using percentages and criteria. The results showed that the implementation of the meaning and symbol recognition did not meet any significant obstacles, the response of parents and early childhood children was very enthusiastic, although some children seemed confused about the meanings and symbols given. The novelty of the research found that parents currently do not really understand and can maintain the ritual intact. The impact of the results of this study is the need to preserve the Modutu ritual so that the children as the successor do not become extinct.
\end{abstract}

Keywords: Introduction; meaning; symbols; traditional plants; modutu; Gorontalo; early childhood.

Copyright (c) 2020 Ellyana Hinta, Sitti Rachmi Masie, Asna Ntelu, Harto S. Malik

$\triangle$ Corresponding author:

Email Address : ellyana.hinta@yahoo.com (Gorontalo, Indonesia)

Received 26 October 2020, Accepted 3 November 2020, Published 6 November 2020 


\section{PENDAHULUAN}

Gorontalo merupakan salah satu daerah yang masih menggunakan sastra lisan seperti puisi, syair, bahkan mantra, beserta benda-benda adat yang diperlukan dalam pelaksanaan berbagai ritual, baik ritual adat maupun ritual keagamaan. Ritual ini dilakukan secara turuntemurun baik di daerah perkotaan dan terlebih lagi di daerah pedesaan. Ritual ini dalam prakteknya selalu melibatkan berbagai aspek, mulai dari orang tua, dewasa, remaja, dan bahkan anak-anak usia dini (Arsa et al., 2019).

Anak-anak usia dini di Gorontalo ini dipandang perlu untuk tetap melestarikan adat istiadatnya sejak dini melalui pendidikan anak usia dini yang merupakan salah satu bentuk penyelenggaraan pendidikan yang menitikberatkan pada pengembangan pembentukan prilaku/pembiasaan meliputi: (1) perkembangan nilai-nilai agama dan moral, (2) perkembangan sosial emosional dan kemandirian dan pengembangan kemampuan dasar. Kemampuan dasar ini salah satunya adalah pengenalan makna dan symbol yang dibelajarkan secara menyenangkan (Srianita et al., 2019).

Perkembangan kedua yang bisa dicapai melalui pengenalan makna dan simbol ini meliputi: (1) perkembangan bahasa, (2) perkembangan kognitif, dan (3) perkembangan fisik motorik. Kegiatan pengembangan suatu aspek dilakukan secara terpadu dengan aspek yang lain dengan menggunakan berbagai macam barang dan alat yang ada pada ritual. Hal ini sesuai dengan fungsi pendidikan anak usia dini, yaitu: membina, menumbuhkan, dan mengembangkan seluruh potensi yang dimiliki anak pada usia dini secara optimal sehingga terbentuk perilaku dan kemampuan dasar sesuai dengan tahap perkembangannya agar memiliki kesiapan untuk memasuki pendidikan dan pengetahuan selanjutnya, dalam hal ini ritual modutu.

Ritual-ritual yang masih ada sangat dekat dengan masyarakat. Ritual yang biasanya berkaitan dengan inti kehidupan manusia yang masih dilakukan diantaranya: (1) ritual keagamaan; (2) ritual kelahiran; (3) ritual pernikahan; (4) ritual kematian; (5) penobatan; dan (6) penyambutan tamu. Setiap ritual adat istiadat itu memiliki tahapan atau prosesi yang dirancang sesuai dengan jenis ritualnya. Ritual-ritual ini bertujuan agar dapat menggambarkan alam pikiran, adat istiadat, kepercayaan, keadaan sosial masyarakat, kepribadian individu, hubungan antar individu serta hubungan diantara individu dan masyarakat, serta pengenalan terhadap sistem yang berlaku di dalam masyarakat tersebut serta upaya untuk melestarikan budaya bagi generasi berikutnya.

Sehubungan dengan hal tersebut, maka artikel ini akan menguraikan pengenalan makna dan simbol bagi anak usia dini terhadap salah satu bagian ritual dari prosesi pernikahan. Artikel ini difokuskan pada pengenalan makna dan simbol struktur dan perangkat adat modutu baik dilihat dari aspek bentuk, fungsi, serta pemaknaan terhadap istilah bahasa Gorontalo khususnya yang berkaitan dengan penamaan beberapa jenis buah/benda adat yang digunakan dalam ritual modutu 'hantaran' tersebut.

Ritual modutu merupakan salah satu rangkaian prosesi upacara pernikahan yang dilaksanakan sebelum acara puncak yang disebut dulahunika atau 'hari pernikahan' dimana dilaksanakan ijab qobul. Melalui ritual ini semua kebutuhan yang digunakan untuk kepentingan pelaksanaan acara puncak termasuk ongkos pernikahan diantarkan dalam bentuk ritual kepada pihak mempelai perempuan sebagaimana sistem yang berlaku selama ini di masyarakat Gorontalo (Baruadi, 2014; Karlan et al., 2020; Lihawa, 2013; Muhammad Gazali Rahman, 2012; Solong \& Arif, 2019; Suhupawati \& Eka Mayasari S. W, 2017).

Adapun benda-benda adat yang diantarkan itu dibicarakan terlebih dahulu oleh kedua belah pihak yang diwakili oleh masing-masing juru bicara melalui pertemuan yang disebut duulohupa 'musyawarah'. Musyawarah dilaksanakan di tempat atau rumah kediaman mempelai perempuan. Pada acara musyawarah tersebut, biasanya pihak mempelai laki-laki akan memberikan gambaran kisaran jumlah ongkos pernikahan beserta hal-hal lainnya yang telah dipersiapkan untuk menjadi tanggungan mereka (Srianita et al., 2019). Jika masih ada hal yang perlu ditambahkan oleh pihak keluarga mempelai laki-laki, maka itu akan 
disampaikan dan dimusyawarahkan secara kekeluargaan hingga mendapatkan keputusan secara mufakat. Semua hasil kesepakatan itulah yang akan diserahkan pada acara ritual modutu termasuk mengantarkan benda-benda adat lainnya.

Di dalam pelaksanaan ritual modutu, pada dasarnya didahului dengan acara 'pelamaran' yang dalam bahasa Gorontalo disebut tolobalango. Akan tetapi kebanyakan acara 'pelamaran' atau tolobalango dilaksanakan secara bersamaan dengan ritual modutu karena alasan kepraktisan dan mengurangi berbagai kesibukan semua pihak.Untuk itu, ketika hantaran dibawa ke rumah mempelai perempuan yang biasanya dilaksanakan pada pukul 15.00 sore, maka waktunya dibagi dalam dua tahapyang diatur seperti berikut:

Pertama, pada pukul 15.30 - 16.00 tokoh agama dan tokoh adat sebagai wakil atau utusan dari keluarga mempelai laki-laki akan melaksanakan acara pelamaran terlebih dahulu sebelum hantaran diturunkan dari kenderaan. Pelamaran itu diwakilkan kepada tokoh adat untuk menyampaikan amanah dari pihak keluarga mempelai laki-laki kepada pihak keluarga mempelai perempuan. Percakapan yang menyangkut pelamaran itu tidak berlangsung lama, karena hal-hal yang akan dibicarakan pada intinya telah disepakati pada acara musyawarah keluarga kedua belah pihak sebelum acara modutu dilakukan.

Kedua, pada pukul 16.00 - 17.00 atau lebih dilanjutkan dengan acara modutu. Pada tahap ini semua perangkat adat yang berkaitan dengan ritual diturunkan dari mobil dan kemudian diantarkan ke rumah calon mempelai perempuan berdasarkan urutan jenis perangkatnya. Petugas yang membawa perangkat-perangkat adat ini adalah bapak-bapak dan didampingi oleh para remaja baik laki-laki maupun perempuan yang mengenakan busana adat Gorontalo. Dalam pengantaran ini biasanya diiringi dengan puisi adat yang disebut tinilo dutu dan dilantunkan oleh ibu-ibu. Mengingat betapa pentingnya adat ini untuk dilestarikan, maka tim penulis perlu melakukan pengenalan makna dan simbol ini bagi anak usia dini dengan harapan mereka akan memahami makna dan simbol tersebut sejak dini dan bisa melestarikan budaya ini kelak (Nurdin \& Anhusadar, 2020).

\section{METODOLOGI}

Metode penelitian yang digunakan dalam penelitian ini adalah metode penelitian deskriptif kualitatif. Sasaran penelitian ini adalah orang tua dan anak usia dini yang ada di Gorontalo, yang berada di sekitar kampus Universitas Negeri Gorontalo. Teknik pengumpulan data menggunakan instrumen angket dan lembar observasi yang telah divalidasi sebelumnya. Teknik analisis data yang digunakan menggunakan teknik ceklis dengan persentase sederhana yang dikonversi ke dalam beberapa kategori (Witarsa \& Dista, 2019).

Kehadiran tim peneliti dalam hal ini sangat penting dalam mengamati jalannya penelitian. Penelitian ini dilakukan pada bulan Februari-April 2020. Subyek penelitian ini adalah orang tua dan anak-anak usia dini yang berjumlah 20 orang. Informan yang ikut membantu beserta cara-cara menggali data-data penelitian diturunkan lima orang dengan tugas masing-masing yang berbeda. Lokasi penelitian bertempat di salah satu Lembaga Pendidikan Anak Usia Dini di sekitar Universitas Negeri Gorontalo. Tahapan penelitian digambarkan sebagai berikut:
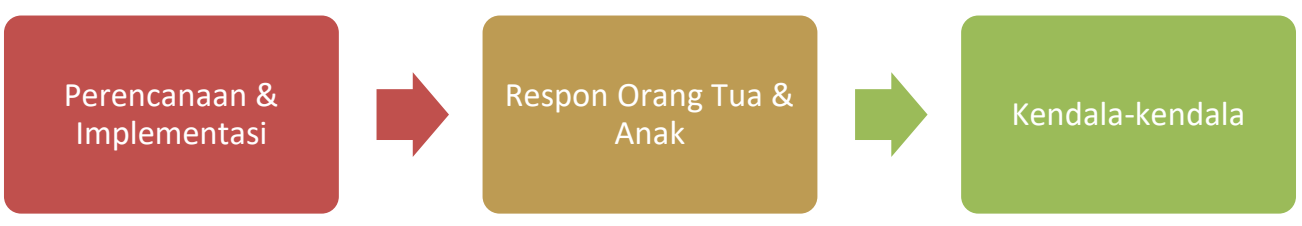

Gambar 1. Tahapan Penelitian

(Sumber: (Witarsa \& Dista, 2019)). 
Pada tahap perencanaan dan implementasi ini tim peneliti membuat instrument angket dan lembar observasi. Kedua instrument tersebut terlebih dahulu divalidasi agar bisa mengukur dengan objektif sesuai dengan tujuan penelitian. Setelah instrument selesai divalidasi, tim peneliti kemudian masuk ke tahap implementasi, yaitu mengamati dan mengobservasi kegiatan modutu yang sudah disiapkan sebelumnya.

Lembar observasi digunakan tim peneliti untuk mengamati respon orang tua dan anak usia dini saat ritual berlangsung. Setelah selesai ritual, para orang tua mengisi angket yang telah disiapkan sebelumnya. Salah satu isi angket tersebut memuat pertanyaan dan pernyataan yang berhubungan dengan kendala-kendala yang dihadapi orang tua dan anak usia dini saat ritual berlangsung.

Lembar observasi dan angket tersebut selanjutnya dikumpulkan, direduksi, dan dianalisis hingga mendapatkan kesimpulan sesuai dengan tujuan penelitian yang telah dirancang sebelumnya.

\section{HASIL DAN PEMBAHASAN}

Berdasarkan metode penelitian yang dilakukan, hasil dan pembahasan terbagi menjadi tiga bagian sebagai berikut: perencanaan dan implementasi, respon orang tua dan anak, serta kendala-kendala yang dihadapi saat penelitian berlangsung. Pada perencanaan dan implementasi ini sesungguhnya tim peneliti tidak menemui kendala yang berarti. Perencanaan dan implementasi sesuai dengan harapan (Dista \& Witarsa, 2020). Adapun kendala-kendala yang ada bisa ditangani segera, sehingga implementasi dapat berjalan dengan baik. Hal ini sejalan dengan hasil penelitian (Baruadi, 2014) yang mengungkapkan bahwa setiap pelaksanaan ritual yang diadakan pada masyarakat Gorontalo, masyarakat antusias dan mendukung lancarnya pelaksanaan ritual.

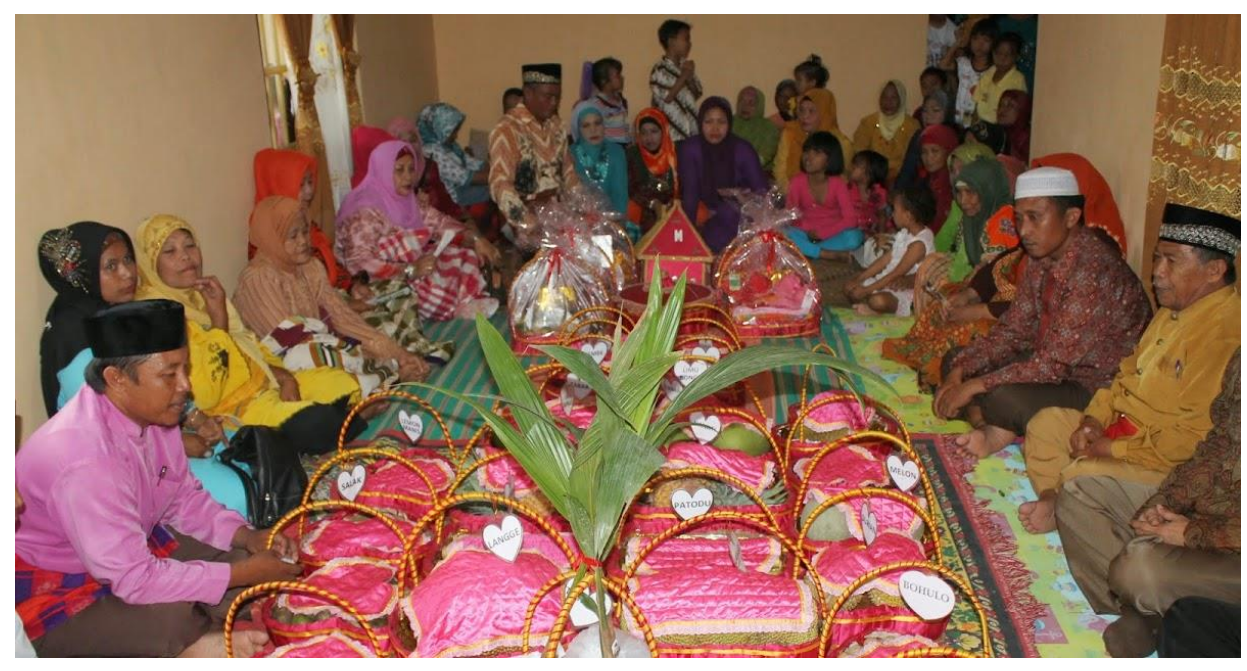

Gambar 2. Perencanaan dan Implementasi Modutu

Pada perencanaan dan implementasi makna dan simbol perangkat ritual modutu ini terdapat berbagai bahan seperti ditunjukan Gambar 2 diatas. Dalam gambar ritual hantaran atau modutu di atas terdapat berbagai material yang dalam bahasa Gorontalo disebut depito dutu "isi hantaran". Isi hantaran yang dijadikan sasaran ritual adalah (1) mahar atau mas kawin, (2) ongkos penyelenggaraan pernikahan, dan (3) perangkat adat (sirih/pinang, dan beraneka macam buah). Semua material adat itu dikemas dalam berbagai bentuk yang menandakan bahwa setiap kemasan memiliki makna serta nilai yang dapat dijadikan pedoman hidup bagi kedua mempelai terutama dalam menjalani kehidupan berumah tangga. Hal ini sangat menarik bagi anak-anak usia dini, dikarenakan mereka sangat tertarik pada perangkat-perangkat tersebut, selain warna-warnanya yang mencolok, mereka juga sering mengajukan pertanyaan terhadap hal-hal baru yang menurut mereka asing. Hal tersebut 
sesuai dengan hasil penelitian bahwa anak-anak usia dini cenderung tertarik dengan barangbarang yang berwarna cerah dan baru bagi mereka (Lihawa, 2013).

Segala sesuatu yang menjadi perangkat adat yang disebutkan diatas kemudian ditata rapi di dalam wadahnya masing-masing dan dimasukkan ke dalam mobil terbuka. Mobil tersebut didekorasi menyerupai perahu dan dihiasi dengan janur. Mobil yang dihiasi tersebut disebut kola-kola. Kola-kola yang berisi perangkat-perangkat adat berada paling depan dan diikuti mobil-mobil lainnya sebagai iring-iringan yang memuat material adat lainnya sebagai tambahan dari hantaran utama. Semakin banyak hantaran, maka semakin banyak pula iringiringan mobil yang membawa isi hantaran atau dutu itu kepada calon mempelai perempuan (Masie et al., 2017).

Isi dutu diturunkan dari yiladia 'rumah' kediaman calon mempelai pria dan selanjutnya diantarkan di yiladia 'rumah' calon mempelai perempuan dengan iringan syair tinilo yang disebut tinilo kola-kola. Syair tinilo itu diiringi pula dengan alat genderang atau tabuhan rebana adat. Isi syair tinilo yang dilantunkan pada dasarnya berisi sanjungan, himbauan, nasihat, harapan, dan doa keselamatan atas kedua mempelai apabila kelak mereka hidup dalam berumahtangga (Ntelu et al., 2020).

Maharu 'mahar' yang diantarkan sebagai benda adat yang merupakan persyaratan ritual modutu ini sebagai berikut: (1) koin 1600 rupiah; (2) koin 48 kati; (3) dingo 'simbol kesepakatan'; (4) tuangokaini. Keempat isi mahar dan maknanya dapat dilihat pada Tabel 1 berikut:

\section{Tabel 1. Isi Mahar dan Maknanya}

\begin{tabular}{|c|c|c|}
\hline No. & Isi Mahar & Makna \\
\hline 1 & Koin sebesar 1600 & $\begin{array}{l}\text { Tanda yang merupakan tonggu. Tonggu adalah warisan leluhur yang juga } \\
\text { sebagai syarat pelengkap ritual modutu. }\end{array}$ \\
\hline 2 & $\begin{array}{l}\text { Koin sebesar } 48 \\
\text { kati }\end{array}$ & $\begin{array}{l}\text { Sebagai syarat pelengkap dutu 'hantaran'. Koin } 48 \text { kati merupakan } \\
\text { penanda adat. Hal ini sebagai simbol besarnya jumlah ongkos pernikahan } \\
\text { yang telah disepakati. }\end{array}$ \\
\hline 3 & Dingo & $\begin{array}{l}\text { Pertanda semua pembicaraan telah disepakati oleh kedua belah pihak. } \\
\text { Dalam bahasa Gorontalo disebut tuoto mololimo 'tanda menerima' semua } \\
\text { material isi hantaran, tanda inilah yang akan melancarkan proses } \\
\text { pembicaraan karena semua ketentuan-ketentuan yang disepakati sejak } \\
\text { awal termasuk penetapan waktu pelaksanaan berupa hari, tanggal, jam, } \\
\text { beserta tempat pelaksanaan, dan sebagainya telah diterima oleh keluarga } \\
\text { kedua belah pihak yang ditandai oleh dingo tersebut. }\end{array}$ \\
\hline 4 & $\begin{array}{l}\text { Tuango kaini 'isi } \\
\text { kain' }\end{array}$ & $\begin{array}{l}\text { Tanda yang merupakan syarat pelengkap dalam ritual dutu. Isi kain pada } \\
\text { dasarnya adalah sadaka 'sedekah' kepada pihak wanita yang akan } \\
\text { dilamar. Sedekah tersebut berupa uang yang akan diberikan oleh pihak } \\
\text { keluarga mempelai laki-laki kepada pihak keluarga mempelai } \\
\text { perempuan. }\end{array}$ \\
\hline 5 & Toyungo 'payung' & $\begin{array}{l}\text { Toyungo ini dimanfaatkan untuk memayungi benda-benda adat ketika } \\
\text { dibawa dan akan memasuki rumah kediaman calon mempelai } \\
\text { perempuan. Simbol toyungo adalah memohon perlindungan dari Sang } \\
\text { Khalik. }\end{array}$ \\
\hline
\end{tabular}

(Sumber: Baruadi, 2014).

Selanjutnya adalah perangkat adat isi Tapahula. Isi tapahula yang dijadikan material hantaran dalam ritual ini terdiri atas dua bagian, yaitu ada perangkat yang bersyarat atau wajib, dan ada pula perangkat yang tidak bersyarat atau tidak wajib. Perangkat yang bersyarat atau wajib berupa; (1) hu'alimo 'cincin' dan seperangkat alat shalat; (2) bada'a 'bedak'; (3) cilak; (4) simengge 'lipstik'; (5) o'ayabu 'kipas'; dan (6) leto 'sapu tangan'; serta (7) ngandhe-ngandhe 'anting'. Ketujuh isi tapahula dan maknanya dijelaskan pada Tabel 2. 
Tabel 2. Isi Tapahula dan Maknanya

\begin{tabular}{|c|c|c|}
\hline No. & Isi Tapahula & Makna \\
\hline 1 & $\begin{array}{l}\text { Hu'alimo 'cincin' } \\
\text { sebagai 'mas } \\
\text { kawin' dan } \\
\text { seperangkat alat } \\
\text { shalat. }\end{array}$ & $\begin{array}{l}\text { Hu'alimo bermakna pengikat bagi seorang pria maupun wanita yang akan } \\
\text { dan telah melakukan ijab qobul. Di sisi lain bahwa orang yang dilamar } \\
\text { telah sepakat untuk menjadi istri dari orang yang melamar. Cincin } \\
\text { membuktikan bahwa wanita yang memakainya adalah pertanda ia telah } \\
\text { resmi menjadi milik dari calon sang suami tersebut, demikian sebaliknya. } \\
\text { Perangkat adat lainnya yang bersamaan dengan cincin yaitu Al-Qur'an } \\
\text { dan mukena. }\end{array}$ \\
\hline 2 & Bada'a "bedak" & $\begin{array}{l}\text { Simbol kecantikan seorang wanita. Bedak sebagai salah satu bagian dari } \\
\text { perangkat adat yang dijadikan isi hantaran ini menandakan bahwa } \\
\text { seorang wanita dalam hal ini istri diharapkan dapat mempercantik bukan } \\
\text { saja wajah tetapi juga mempercantik batinnya agar tidak terterima baik } \\
\text { dalam lingkungan keluarga maupun dalam lingkungan masvarakat. }\end{array}$ \\
\hline 3 & $\begin{array}{l}\text { Cilak "hiasan } \\
\text { mata" }\end{array}$ & $\begin{array}{l}\text { Tanda bahwa seorang wanita yang telah dilamar, harus menjaga mata, } \\
\text { agar tidak banyak melihat hal-hal yang tidak berguna. }\end{array}$ \\
\hline 4 & Simengge 'lipstik' & $\begin{array}{l}\text { Sebagai penghias bibir, dalam arti bahwa bibir seorang wanita (istri) } \\
\text { harus cantik dengan tidak selalu menebar fitnah, berkata-kata jorok, } \\
\text { menipu, atau berbohong, dan juga tidak boleh menggunjing, beserta } \\
\text { penyakit kata lainnya yang sering menjadi hiasan bibir dari seorang } \\
\text { perempuan. Itu merupakan simbol dari pemerah bibir, yang artinya } \\
\text { bukan merah yang berani atau suka melukai hati orang lain. }\end{array}$ \\
\hline 5 & O'ayabu 'kipas' & $\begin{array}{l}\text { Kipas berfungsi sebagai pohuhulo 'pendingin' yang artinya bahwa wanita } \\
\text { yang akan dilamar diharapkan agar senantiasa hatinya dalam keadaan } \\
\text { sejuk dan bersih. }\end{array}$ \\
\hline 6 & Leto 'sapu tangan' & $\begin{array}{l}\text { Leto'sapu tangan' atau lenso sebagai pertanda bahwa seorang perempuan } \\
\text { terlebih sebagai seorang istri harus dalam keadaan bersih terutama kedua } \\
\text { tangannya. Kebersihan tangan dalam pengertian ini adalah bahwa } \\
\text { tangan bersih tidak saja dalam arti harfiah melainkan dalam arti tersirat. }\end{array}$ \\
\hline 7 & $\begin{array}{l}\text { Ngandhe-ngandhe } \\
\text { 'anting' }\end{array}$ & $\begin{array}{l}\text { Anting bermakna bahwa seorang wanita sebagai calon mempelai dan } \\
\text { sebagai calon istri, diharapkan agar banyak menyimak hal-hal yang baik } \\
\text { dan bermanfaat. Hal ini identik dengan hiasan yang akan mempercantik } \\
\text { telinga dengan anting atau yang disebut ngandhe-ngandhe. Telinga selalu } \\
\text { dipelihara dari pendengaran atas hal-hal yang tidak berguna dalam } \\
\text { keberlangsungan hidup di dunia ini. }\end{array}$ \\
\hline
\end{tabular}

(Sumber: Karlan et al., 2019).

Itulah beberapa simbol yang terdapat pada benda-benda adat yang dijadikan sebagai perangkat wajib dalam ritual modutu. Setiap benda adat memiliki makna yang dapat difungsikan sebagai nasihat kepada kedua calon mempelai terutama calon mempelai perempuan yang akan menjalani hidup berumah tangga. Melalui benda-benda adat itu diharapkan kedua mempelai akan menjaga beberapa indra seperti mata, hati, mulut, telinga, dan anggota tubuh lainnya seperti tangan, agar selalu dipelihara kesuciannya, dan dijauhkan dari hal-hal yang mendatangkan dosa dan maksiat, karena semua itu akan dimintai pertanggungjawaban kelak di hari kemudian (Muhammad Gazali Rahman, 2012). Oleh sebab itu, benda-benda adat di atas dijadikan isi tapahula yang diantarkan kepada calon mempelai perempuan melalui ritual modutu.

Disamping perangkat adat yang wajib, ada pula perangkat yang tidak wajib seperti pakaian, sepatu, sandal, tas, seprey/selimut dan bahan untuk tata rias wajah lainnya baik yang berbentuk tradisional maupun modern, beserta perlengkapan mandi dan lain-lain yang dianggap perlu dihadiahkan oleh mempelai pria kepada mempelai perempuan sebagai calon istrinya. Isi tapahula seperti ini merupakan perangkat sampingan dalam ritual dutu sehingga yang mengikutsertakan perangkat ini biasanya hanyalah orang tertentu yang mau dan mampu menyiapkannya karena bukan merupakan persyaratan yang dituntut sesuai adat 
istiadat yang berlaku di daerah Gorontalo. Namun demikian, dengan adanya perkembangan yang terjadi di masyarakat, maka perangkat-perangkat seperti itu telah dianggap wajib karena adanya budaya ikut-ikutan atau meniru.

Pemaknaan terhadap benda-benda sebagai isi tapahula di atas, didasarkan pada fungsi dari masing-masing jenis perangkatnya, setiap aktivitas kebudayaan yang tentu beserta perangkatnya haruslah berfungsi terlebih dahulu barulah akan bermakna. Sebaliknya, bahwa setiap aktivitas kebudayaan yang sudah berfungsi dan atau difungsikan secara baik dengan sendirinya memiliki makna. Dengan kata lain, makna selalu diartikan sebagai mengandung nilai-nilai positif untuk kesejahteraan umat manusia. Setiap benda akan berfungsi secara efisien sesuai dengan hakekatnya masing-masing.

Dengan demikian, benda-benda adat tersebut karena dianggap berfungsi untuk membentuk perilaku manusia dalam menjalani kehidupannya, baik dalam kehidupan keluarga maupun dalam kehidupan bermasyarakat maka perlu dimaknai berdasarkan fungsi sebagaimana dikemukakan diatas.

Berikutnya adalah penjelasan menenai Tonggu. Tonggu merupakan salah satu wadah yang didalamnya berisi seperangkat sirih/pinang sebagai penanda bahwa ritual ini merupakan ritual adat yang wajib mempersembahkan sirih dan pinang kepada para tetamu yang diundang dalam suatu hajatan. Isi tonggu dan maknanya diuraikan pada Tabel 3 berikut:

Tabel 3. Isi Tonggu dan Maknanya

\begin{tabular}{|c|c|c|}
\hline No. & Isi Tonggu & Makna \\
\hline 1 & Tembe 'sirih' & $\begin{array}{l}\text { Tembe 'sirih' merupakan lindhidu aadati 'urat adat' artinya sebagai syarat } \\
\text { kelengkapan dalam sitem peradatan. }\end{array}$ \\
\hline 2 & $\begin{array}{l}\text { Luhuto } \\
\text { pinang' }\end{array}$ & $\begin{array}{l}\text { Luhuto juga merupakan syarat penting sebagai sesuatu yang harus ada } \\
\text { dalam ritual modutu. Sebagai perangkat yang harus berpasangan dengan } \\
\text { sirih maka pinang tersebut tidak boleh ditinggalkan dalam kaitannya } \\
\text { dengan pelaksanaan adat istiadat yang diadakan di daerah Gorontalo. }\end{array}$ \\
\hline 3 & Taba'a 'tembakau' & $\begin{array}{l}\text { Taba'a atau 'tembakau' merupakan sesuatu yang dijadikan pelengkap } \\
\text { bagi orang yang telah selesai mengunyah sirih-pinang. Jika melihat } \\
\text { bentuknya yang mirip dengan bentuk rambut maka tembakau dalam } \\
\text { sistem peradatan di Gorontalo diibaratkan sebagai hapato yakni berupa } \\
\text { bulu halus yang tumbuh di atas kulit dan biasanya disebut 'bulu roma'. }\end{array}$ \\
\hline 4 & Gambele 'gambir' & $\begin{array}{l}\text { Gambele yang dipersyaratkan dalam sistem peradatan ini dimaknai pula } \\
\text { dari aspek bentuk beserta warnanya. Untuk itu gambele diibaratkan } \\
\text { sebagai duhu lo aadati atau 'darahnya adat'. }\end{array}$ \\
\hline
\end{tabular}

Dengan demikian, khusus untuk benda adat yang disebutkan pada empat jenis terakhir, yaitu sirih, pinang, tembakau, dan gambir, merupakan satu paket yang diibaratkan sebagai bagian atau organ tubuh yang tidak dapat dipisahkan satu sama lain untuk membentuk kehidupan setiap manusia. Demikian pula keberlangsungan hidup adat istiadat yang berlaku bagi masyarakat Gorontalo yang dipertahankan secara turun temurun (Solong \& Arif, 2019).

Selain buah-buahan bersyarat, ada pula buah-buahan yang tidak bersyarat seperti apel, sunkist, salak, mangga, manggis, duku, semangka, pepaya, jeruk manis, pisang, rambutan, sirsak, lengkeng, dan anggur yang dibawakan kepada pihak mempelai perempuan dengan tujuan untuk lebih memeriahkan agar buah-buahan itu dapat dijadikan sedekah kepada sanak keluarga dan kerabat yang menunggu pelaksanaan acara hantaran tersebut.

Uraian makna terhadap beberapa perangkat buah-buahan seperti dikemukakan diatas merupakan penamaan buah yang berbahasa Gorontalo kemudian diasosiasikan dengan sifatsifat atau tindakan manusia dalam setiap aktivitas kehidupannya sehari-hari. Proses penamaan sesuatu itu biasanya berkaitan dengan acuannya (Suhupawati \& Eka Mayasari S. W, 2017). Penamaan bersifat konfensional dan arbitrer. Konvensional berdasarkan kebiasaan masyarakat pemakainya, sedangkan arbitrer berdasarkan kemauan masyarakatnya. Begitu 
pula dengan pemaknaan terhadap penamaan (penyebutan) buah-buahan yang dijadikan perangkat adat dalam ritual modutu di Gorontalo.

Tabel 4. Jenis Buah dan Maknanya

\begin{tabular}{|c|c|c|}
\hline No. & Jenis Buah & Makna \\
\hline 1 & $\begin{array}{l}\text { Tumula } \\
\text { kelapa' }\end{array}$ & $\begin{array}{l}\text { Bermakna sebagai biisalawa yang berarti "pembicaraan awal". Kata } \\
\text { "awal" diambil dari istilah "tunas", karena "tunas" dalam bahasa } \\
\text { Gorontalo tumula bermakna "mengawali". Jadi tumula dalam ritual ini } \\
\text { dipadankan dengan kata "pembicaraan, kesepakatan, atau ikrar", yang } \\
\text { telah disampaikan dihadapan khalayak dan sanak keluarga sehubungan } \\
\text { dengan pelaksanaan prosesi akad nikah pada hari pernikahan. }\end{array}$ \\
\hline 2 & $\begin{array}{l}\text { Limubongo 'jeruk } \\
\text { Bali' }\end{array}$ & $\begin{array}{l}\text { Limu merupakan nama buah yang kemudian dimaknai dalam bahasa } \\
\text { Gorontalo menjadi limomota artinya 'sempurna'. Kata sempurna atau } \\
\text { kesempurnaan diharapkan agar seseorang baik yang akan dilamar } \\
\text { maupun sang pelamar dapat dikatakan sebagai orang yang sempurna } \\
\text { tanpa ada cacat celah atau kekurangan sedikitpun. }\end{array}$ \\
\hline 3 & Langge 'nangka' & $\begin{array}{l}\text { Simbol buah langge dimaknai pula dari aspek istilah. Langge diartikan } \\
\text { sebagai kata yang memiliki makna langgelo. Istilah langgelo dalam bahasa } \\
\text { Gorontalo artinya 'melihat ke atas'. Melihat keatas yang dimaksudkan } \\
\text { dengan istilah ini bukan saja berarti menjadikan diri sebagai orang yang } \\
\text { angkuh atau sombong karena kerapkali membandingkan dirinya } \\
\text { dengan orang yang lebih tinggi status sosialnya. Akan tetapi melihat ke } \\
\text { atas dalam hal ini bemakna bahwa setiap gerak-gerik hendaknya akan } \\
\text { selalu berpegang teguh pada aturan Allah SWT sebagaimana yang } \\
\text { dicontohkan oleh baginda Nabi besar Muhammad SAW. }\end{array}$ \\
\hline 4 & Nanati 'nenas' & $\begin{array}{l}\text { Istilah nanati memiliki penggalan kata yakni nana yang bermakna 'ibu'. } \\
\text { Artinya orang yang sangat berpengaruh dalam kehidupan manusia } \\
\text { sehingga patut dihargai dan dihormati. Pada hakekatnya ritual dutu ini } \\
\text { merupakan bukti penghormatan dari pihak yang melamar terhadap } \\
\text { orang yang akan dilamar. }\end{array}$ \\
\hline 5 & Patodu 'tebu' & $\begin{array}{l}\text { Istilah patodu dalam bahasa Gorontalo artinya 'tebu' memiliki padanan } \\
\text { kata po'olingalio yang berarti 'pemanis'. Sebuah pengharapan dari makna } \\
\text { ini ialah ketulusan dari kedua belah pihak yang ditandai dengan } \\
\text { ekspresi wajah yang berseri sehingga terlihat gerak-gerik, karakter yang } \\
\text { bermuka manis. Makna yang lebih utama adalah bahwa orang yang } \\
\text { melakukan pelamaran mengharapkan agar seorang wanita yang akan } \\
\text { dilamar senantiasa bermanis hati di samping bermanis wajah. }\end{array}$ \\
\hline
\end{tabular}

Setiap istilah bahasa Gorontalo yang terkait dengan penyebutan buah itu, diterjemahkan ke dalam bahasa Indonesia, kemudian istilah itu diuraikan berdasarkan pengertiannya. Pengertian itu memunculkan makna yang dikaitkan dengan nasihat kepada orang yang dituju yakni kedua mempelai sebagai audiens primer, dan juga kepada hadirin sebagai audiens sekunder. Sehubungan dengan itu, perangkat adat yang bersyarat lainnya adalah terkait dengan aneka buah atau hungoloayu 'aneka buah'. Buah-buahan yang dijadikan persyaratan adalah buah yang memiliki nilai dan makna berdasarkan penamaan atau istilah dari masing-masing jenis buah tersebut. Untuk itu benda adat berupa buah dimaksud akan diuraikan sebagai berikut.

Hungo lo ayu yang artinya 'buah pohon' dalam adat Gorontalo disebut sebagai 'adati lo hunggia he baki-bakia' artinya 'adat Gorontalo berbaki-baki'. Yang dimaksud berbaki-baki' adalah bahwa adat istiadat yang digunakan di Gorontalo beraneka-ragam dan digunakan sesuai jenis ritual yang dilaksanakan. Hal ini dijadikan media pengirim pesan yang disampaikan kepada khalayak dengan harapan agar nilai-nilai yang terkandung didalamnya dapat diimplikasikan dalam kehidupan sehari-hari (Suyadi \& Selvi, 2019). 
Demikian pula dengan beberapa jenis hungo lo ayu 'buah-buahan' sebagai tanda atau syarat pelengkap dutu "pelamaran". Dengan adanya makna kata/istilah untuk setiap nama buah tersebut, maka diharapkan kedua mempelaipun akan mengikuti sifat-sifat sesuai makna kata pada setiap jenis buah dimaksud. Istilah atau nama buah yang wajib sebagai perangkat ritual adat itu berupa; (1) tumula 'tunas kelapa'; (2) limu'jeruk' berukuran besar yang biasanya disebut 'jeruk Bali': (3) langge'nangka'; (4) nanati 'nenas'; (5) patodu'tebu'.

Untuk kepentingan penanaman nilai-nilai agama dan adat istiadat, maka para tokoh agama, tokoh adat, dan tokoh masyarakat menyepakati bahwa beberapa jenis buah yang dikemukakan diatas dapat dijadikan perangkat adat yang wajib dalam ritual modutu. Ini disebabkan karena setiap nama jenis buah itu sangat identik dengan sifat-sifat mulia yang membawa seseorang kepada kesantunan berbahasa maupun kesantunan bersikap, hormat kepada orang tua, memiliki peradaban yang tinggi, berbudi baik, peduli terhadap sesama, taat beribadah, berprilaku baik, serta berakhlak mulia (Halimatus et al., 2019). Sifat-sifat inilah yang menjadi harapan semua pihak agar kedua mempelai kelak menjadi pasangan yang taat beragama di samping memiliki akhlak yang mulia. Makna kata/istilah sesuai jenis buah akan diuraikan pada Tabel 4.

Pada bagian kedua adalah mengamati respon orang tua dan anak usia dini terhadap pengenalan makna dan simbol perangkat tanaman adat dalam ritual modutu. Respon ini menunjukkan respon yang diberikan oleh orang tua yang mewakili anak usia dini, dikarenakan anak usia dini belum pandai menulis. Respon yang ditunjukkan anak usia dini dapat dilihat pada Tabel 5.

Hasil angket respon orang tua dan anak terhadap pengenalan makna dan simbol perangkat tanaman adat dalam ritual modutu tersebut menunjukkan hasil bahwa pengenalan makna dan simbol perangkat tanaman adat dalam ritual modutu menunjukkan interpretasi skor angket Baik (skor rata-rata diatas 75) (Witarsa \& Dista, 2019). Hal ini menunjukkan bahwa baik orang tua dan anak-anak sangat antusias terhadap pengenalan makna dan simbol modutu. Bahkan ada juga orang tua yang belum paham akan makna-makna yang ada.

Tabel 5. Respon Anak Usia Dini

\begin{tabular}{cccccc}
\hline No. & Kode Anak Usia Dini & Jumlah & No & Kode Anak Usia Dini & Jumlah \\
\hline 1 & ADK & 74 & 11 & GT & 92 \\
2 & AZ & 77 & 12 & HJ & 79 \\
3 & BA & 77 & 13 & KL & 82 \\
4 & BM & 80 & 14 & MB & 91 \\
5 & CK & 75 & 15 & RS & 78 \\
6 & CC & 63 & 16 & TY & 81 \\
7 & DN & 82 & 17 & VD & 76 \\
8 & DNN & 76 & 18 & XS & 74 \\
9 & EF & 79 & 19 & YU & 82 \\
10 & FR & 84 & 20 & ZA & 82 \\
& & & Rata- & 79,2 & \\
& & rata & & \\
\hline
\end{tabular}

Pada bagian ketiga adalah kendala-kendala yang dihadapi oleh orang tua dan anak dalam pengenalan makna dan simbol perangkat tanaman adat dalam ritual modutu.

Dapat dilihat pada Gambar 3 bahwa nampak kendala-kendala yang dihadapi orang tua dan anak adalah orang tua sedikit kesulitan untuk mengarahkan anaknya untuk bisa fokus sepanjang waktu untuk mengenal makna dan simbol modutu. Sementara anak yang masih santainya melakukan kegiatannya sendiri. Sikap acuh tak acuh anak usia dini menjadi kendala saat pengenalan awal. 
Untuk mengatasi kendala-kendala yang terjadi saat pengenalan makna dan simbol ritual, peneliti bersama dengan orang tua melakukan hal-hal pengalih perhatian. Jadi saat anak-anak terlihat mulai bosan, peneliti dan orang tua mulai mengenalkan barang-barang yang lain dan nampak menarik bagi anak. Pengenalan makna dan simbol dilakukan dengan teknik bermain dan menyenangkan.

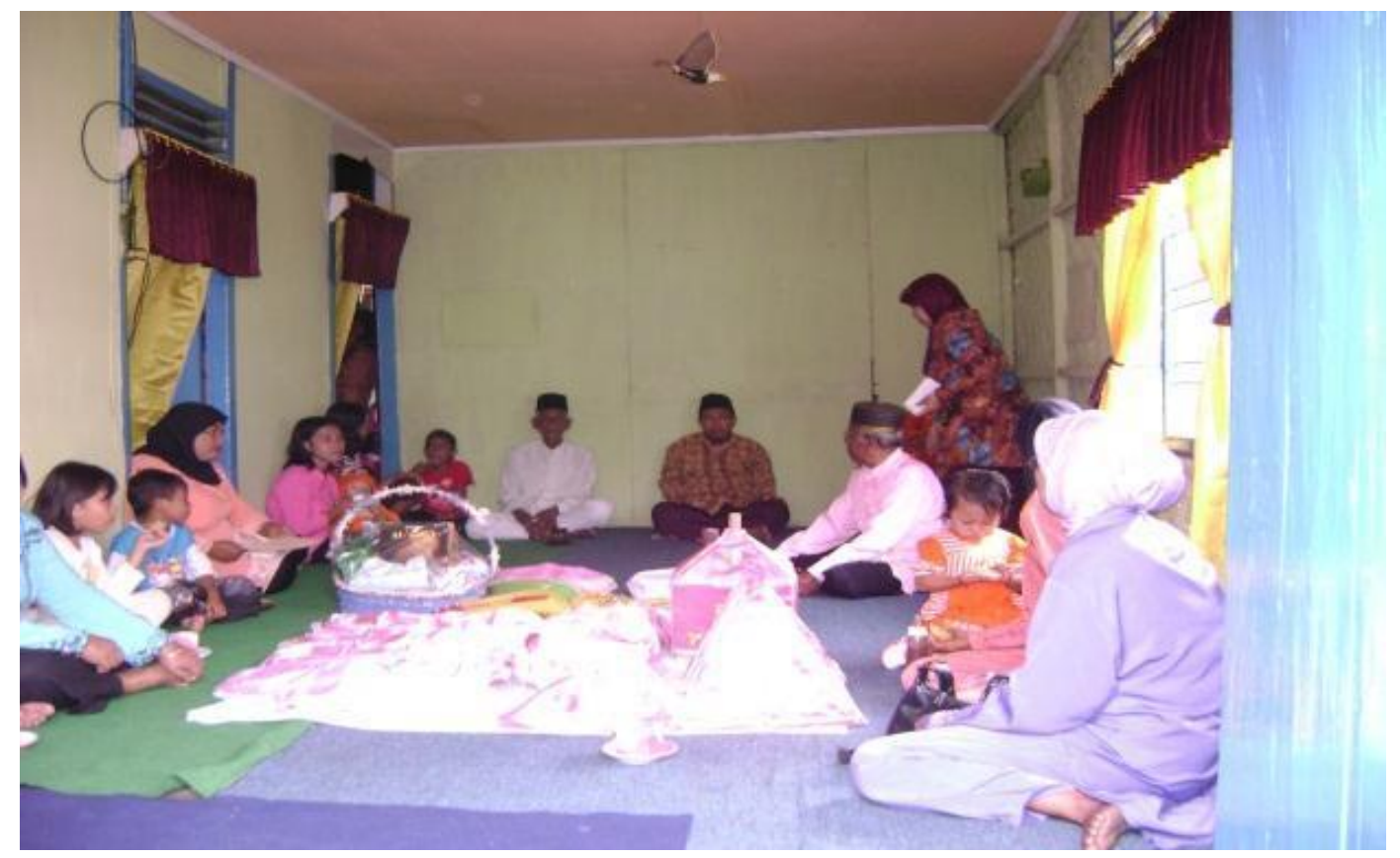

Gambar 3. Kendala-kendala yang Dihadapi Orang Tua dan Anak

\section{SIMPULAN}

Pengenalan makna dan simbol modutu bagi anak usia dini di Gorontalo tidak menemui kendala yang berarti, respon orang tua dan anak-anak usia dini sangat antusias dengan kategori baik. Modutu merupakan perangkat peradatan yang harus dipersiapkan oleh pihak mempelai laki-laki dan yang akan diantarkan kepada pihak mempelai perempuan melalui ritual adat modutu 'hantaran' sebagai awal proses suatu pernikahan. Kebaruan penelitian didapatkan bahwa orang tua saat ini tidak terlalu paham dan dapat mempertahankan ritual tersebut secara utuh. Dampak dan impak dari hasil penelitian ini adalah perlunya dilestarikan kembali ritual modutu agar anak-anak sebagai penerus tidak punah digilas zaman.

\section{UCAPAN TERIMA KASIH}

Tim penulis mengucapkan terima kasih kepada Universitas Negeri Gorontalo, Pendidikan Anak Usia Dini, Orang Tua, dan Anak-anak yang telah memberi dukungan terhadap terlaksananya penelitian ini. Tim penulis juga mengucapkan terima kasih kepada Pengelola Jurnal Obsesi yang telah memberi review dan masukan atas terbitnya artikel ini.

\section{DAFTAR PUSTAKA}

Arsa, D., Atmazaki, A., \& Juita, N. (2019). Literasi Awal pada Anak Usia Dini Suku Anak Dalam Dharmasraya. Jurnal Obsesi: Jurnal Pendidikan Anak Usia Dini, 3(1), 127. https:// doi.org/10.31004/obsesi.v3i1.159

Baruadi, M. K. (2014). Tradisi Sastra Dikili Dalam Pelaksanaan Upacara Adat Maulidan Di Gorontalo. El-HARAKAH https:// doi.org/10.18860/el.v16i1.2760

(TERAKREDITASI), $\quad 16(1), \quad 1$.

Dista, D. X., \& Witarsa, R. (2020). Analisis Pengetahuan Siswa melalui Pembelajaran Penemuan di Sekolah Dasar Pahlawan. Jurnal Elementary Metro, 6(1), 1-9. 
DOI: 10.31004/obsesi.v5i2.835

Halimatus, H., Fridani, L., \& Meilani, S. M. (2019). Pengembangan Media Grafis untuk Pengenalan Life Science pada Anak Usia Dini. Jurnal Obsesi : Jurnal Pendidikan Anak Usia Dini, 4(1), 395. https://doi.org/10.31004/obsesi.v4i1.318

Karlan, L. O., Rahmat, A., \& Mirnawati, M. (2020). Pendidikan Masyarakat Pada Pertunjukan Turunani Dalam Upacara Adat Gorontalo. Aksara: Jurnal Ilmu Pendidikan Nonformal, 5(3), 163. https:// doi.org/10.37905/aksara.5.3.163-170.2019

Lihawa, K. (2013). Leksikon Dan Nilai Kultur Suwawa-Gorontalo Dalam Ritual Momeqati. Bahasa Dan Seni, 41(1), 40-51. http://sastra.um.ac.id/wpcontent/uploads/2014/02/5-Kartin-Lihawa-ok.pdf

Masie, S. R., Siswanto, W., Pratiwi, Y., \& Suwignyo, H. (2017). Students' Motivation and Appreciation on The Teaching of Writing Short Story Based on Creative-Literacy. Journal of Educational Science and Technology (EST), 3(3), 226. https://doi.org/10.26858/est.v3i3.4200

Muhammad Gazali Rahman. (2012). TRADISI MOLONTHALO DI GORONTALO. Jurnal AlUlum, 12(Vol. 12 No. 2 (2012): Al-Ulum), 437-456. http://journal.iaingorontalo.ac.id/index.php/au/article/download/109/93

Ntelu, A., Hinta, E., Yasin, Y., \& Supriyadi. (2020). Bahasa figuratif dalam puisi-puisi karya Chairil Anwar. Aksara: Jurnal Bahasa Dan Sastra, 21(1), 41-56.

Nurdin, N., \& Anhusadar, L. O. (2020). Evaluasi Pelaksanaan Standar Proses di Satuan Pendidikan Anak Usia Dini. Jurnal Obsesi : Jurnal Pendidikan Anak Usia Dini, 4(2), 982. https://doi.org/10.31004/obsesi.v4i2.485

Solong, N. P., \& Arif, M. (2019). The Marriage Procession Outside the Marriage Hall and its Impact on Children 's Education for Gorontalo Communities. Jurnal Al-Ulum, 19(2), 443-462.

Srianita, Y., Akbar, M., \& Meilanie, S. M. (2019). Pembentukan Karakter dalam Pendidikan Makan (Studi Kasus di Raudhatul Athfal Istiqlal Jakarta). Jurnal Obsesi: Jurnal Pendidikan Anak Usia Dini, 4(1), 152. https:/ / doi.org/10.31004/obsesi.v4i1.277

Suhupawati, S., \& Eka Mayasari S. W, D. (2017). Upacara adat kelahiran sebagai nilai sosial budaya pada masyarakat suku sasak desa pengadangan. Historis | FKIP UMMat, 2(2), 15. https:// doi.org/10.31764/historis.v2i2.188

Suyadi, S., \& Selvi, I. D. (2019). Implementasi Mainan Susun Balok Seimbang Berbasis Kearifan Lokal Yogyakarta untuk Anak Usia Dini. Jurnal Obsesi: Jurnal Pendidikan Anak Usia Dini, 4(1), 385. https:// doi.org/10.31004/obsesi.v4i1.345

Witarsa, R., \& Dista, D. X. (2019). Analisis Jawaban Siswa Usia 6 sampai 8 tahun terhadap Pembelajaran Sains Kreatif. Jurnal Obsesi : Jurnal Pendidikan Anak Usia Dini, 4(1), 58. https://doi.org/10.31004/obsesi.v4i1.288 